Article

\title{
An Environmental Justice Assessment of the Waste Treatment Facilities in Shanghai: Incorporating Counterfactual Decomposition into the Hedonic Price Model
}

\author{
Can Zou ${ }^{1,2,3}$, Jun Tai ${ }^{4}$, Li Chen ${ }^{1,2,3}$ and Yue Che ${ }^{1,2,3, *}$ \\ 1 School of Ecological and Environmental Sciences, East China Normal University, Shanghai 200062, China; \\ ECNU_Zoc@outlook.com (C.Z.); chenli@hdsdhz.onaliyun.com (L.C.) \\ 2 Shanghai Key Laboratory of Urbanization and Ecological Restoration, East China Normal University, \\ Shanghai 200062, China \\ 3 Institute of Eco-Chongming (IEC), East China Normal University, Shanghai 200062, China \\ 4 Shanghai Environmental Engineering Design Research Institute, Shanghai 200232, China; \\ taijun8011@163.com \\ * Correspondence: yche@des.ecnu.edu.cn; Tel.: +86-21-54341060
}

Received: 28 February 2020; Accepted: 15 April 2020; Published: 20 April 2020

\begin{abstract}
Environmental justice (EJ) has become an increasingly significant issue for environmental management and has thus attracted increasing government and public attention. Although some studies have used techniques of proximity based on geographical information systems to assess EJ, their research is limited to individual or household data. Unlike the conventional hedonic price model (HPM) examining the effects of environmental features on housing rent, this article incorporates counterfactual decomposition into the HPM to estimate the environmental pressure on different groups by comparing the externality effects of municipal solid waste treatment facilities (MSWTFs) on two separate groups of people. To explore whether and, if so, the extent to which, vulnerable groups of people are restricted to disproportionate impacts of hazardous environmental facilities, this research uses Shanghai as the study area to highlight specific locations and exemplify the environmental injustice between the rich and the poor. The results, which represent the relationship between environmental quality and property prices, indicate that environmental quality is a robust predictor of housing rent. Simultaneously, the results suggest that some people conform better to environmental pressure than do others. Thus, the environmental impact of MSWTFs on different populations should be considered, and compensation policies should be implemented for disadvantaged groups.
\end{abstract}

Keywords: environmental justice; hedonic price model; municipal solid waste treatment facilities; Shanghai

\section{Introduction}

The discussion of environmental justice (EJ) dates back to the 1980s [1-3], with many studies concluding that disadvantaged groups throughout the country suffer from having a disproportionate share of municipal solid waste treatment facilities (MSWTFs) within their proximity [4-6]. Since the 1980s, researchers have been finding that certain racial and ethnic groups are being disproportionately targeted with respect to the location of MSWTFs and determining the extent to which this is occurring [7-9]. Since then, the U.S. Environmental Protection Agency (EPA) has focused on this issue and has provided the following official definition of EJ: No one of any race, culture, income or education level should be forced to bear a disproportionate share of exposure to the negative 
impact of pollution [10]. At present, environmental injustice is widespread throughout the world, including China [11-13]. Previous research has compared the demographic characteristics of areas with MSWTFs with those of areas without MSWTFs in the survey region using spatial coincidence and buffering analysis [14-16]. While these studies have found that families living in poor communities are likely to be closer to MSWTFs than are those living in rich communities, different buffer sizes and buffer analysis methods have led to contradictory or varying conclusions for the same geographical region [17]. In addition, as some geographic units of analysis, such as census areas, have no reported income, it is difficult to consider poverty in EJ studies [18]. Hence, these limitations may restrict the wider applicability and generalizability of the research results [19].

As studies that associate EJ with racial and income characteristics are becoming increasingly more prevalent in environmental economics and management [20], this article extends the existing approaches by incorporating counterfactual decomposition into the hedonic price model (HPM). Generally, the conventional HPM infers the marginal price of any characteristic variable using the variation in the dependent variable and the independent variables [21]. For instance, the distance between a house and the nearest MSWTF is usually regarded as an environmental quality indicator [22]. Accordingly, the closer in distance a house is to the MSWTF, the lower the housing rent. Several studies have therefore used the HPM to estimate the hedonic price of refusing waste landfill sites and waste incineration plants [23]. Similar models have been used by Hughes and Madden [24] to analyze urban economists and used by Oaxaca [25] to test for wage discrimination. This study is based on real estate transaction data and uses urban locations and hedonic price models to test for discrimination. As market data can provide alternative measures regarding the extent of environmental hazards, rather than using traditional proximity measures [26], this paper incorporates counterfactual decomposition into the HPM as a basis for EJ analysis. In the study of EJ, the principal question is whether the effect of disamenity depends on the distance between the house and the nearest MSWTF among different groups of people. The HPM is useful to analyze this problem, since it can convert the housing price into expenditures on individual property characteristics, such as environmental quality. Therefore, people from different ethnicities and races are divided into two or more groups, and their data are introduced into the model to analyze EJ in the housing market.

In contrast to previous evidence, Table 1 reports 15 studies using the HPM and other methods to evaluate the effect of hazardous sites on different groups of people. The environmental effects of MSWTFs are discussed with respect to environmental disamenities in these studies on EJ, such as waste landfill sites, waste incineration plants and Superfund National Priorities List (NPL) sites. These studies attempt to identify the extent/distance to which the effects of these hazardous sites can reach. Most studies using other methods report that the effects disappear within 5 miles, while the results of the HPM indicate that price effects can reach approximately 6 miles $(10 \mathrm{~km})$, and the conclusion of this study well supports these findings. Thus, environmental price discrimination may extend to price differentials in individual property characteristics within a larger scope. As a consequence, this study discusses that the marginal price differences in environmental quality estimated using the HPM can be utilized to determine EJ for different groups of people within $10 \mathrm{~km}$. This study also reviews the more vulnerable people who are being impacted by hazardous sites, whether it be the poor, Hispanics, nonwhite populations, other marginalized groups or a combination thereof. Given China's situation, it is difficult to observe the residential segregation of race and ethnicity around MSWTFs. However, this difficulty does not influence the appearance of environmental injustice between the poor and the rich, a premise that is supported by this study's HPM test. 
Table 1. Summary of Hazardous Site Impact Studies.

\begin{tabular}{|c|c|c|c|c|}
\hline Study & Hazard & $\begin{array}{l}\text { Max. Distance } \\
\text { of Effect }\end{array}$ & Object & Method \\
\hline Hite et al., 2001 [27] & $\begin{array}{l}\text { Four landfill sites in } \\
\text { Franklin, Ohio, US }\end{array}$ & 3.25 miles & Households & Hedonic price \\
\hline $\begin{array}{l}\text { Ihlanfeldt and } \\
\text { Taylor, 2004 [28] }\end{array}$ & $\begin{array}{l}\text { Hazardous waste sites } \\
\text { in Atlanta, Georgia, US }\end{array}$ & 2 miles & $\begin{array}{l}\text { High- and low-income } \\
\text { neighborhoods }\end{array}$ & $\begin{array}{l}\text { Multiple-equilibrium } \\
\text { hedonic model }\end{array}$ \\
\hline $\begin{array}{l}\text { Kiel and Williams, } \\
2007 \text { [29] }\end{array}$ & $\begin{array}{l}57 \text { NPL sites in } 20 \\
\text { counties in the US }\end{array}$ & 3 miles & Blue-collar workers & Hedonic price \\
\hline $\begin{array}{c}\text { Higgs and } \\
\text { Langford, 2009 [19] }\end{array}$ & $\begin{array}{c}\text { Landfill site in Wales, } \\
\text { UK }\end{array}$ & $4 \mathrm{~km}$ & Minority communities & Hedonic price \\
\hline $\begin{array}{c}\text { Noonan et al., } \\
2009[20]\end{array}$ & NPL sites in Texas, US & 6 miles & $\begin{array}{l}\text { Blacks, Hispanics, the } \\
\text { poor }\end{array}$ & Hedonic price \\
\hline $\begin{array}{l}\text { Yeboah et al., } \\
2009[30]\end{array}$ & $\begin{array}{l}\text { Hog producer in North } \\
\text { Carolina, US }\end{array}$ & No discussion & $\begin{array}{l}\text { Poor and nonwhite } \\
\text { populations }\end{array}$ & $\begin{array}{l}\text { Regression analyses and } \\
\text { longitudinal analysis }\end{array}$ \\
\hline $\begin{array}{l}\text { Giordano and } \\
\text { Cheever, } 2010 \text { [31] }\end{array}$ & $\begin{array}{c}\text { Hazardous waste } \\
\text { generators in Bexar, US }\end{array}$ & $3 \mathrm{~km}$ & $\begin{array}{l}\text { Minorities, the poor, } \\
\text { and non-homeowners }\end{array}$ & Dasymetric mapping \\
\hline $\begin{array}{l}\text { Perera et al., } \\
2013 \text { [32] }\end{array}$ & $\begin{array}{l}\text { Toxic release inventory } \\
\text { sites in the Mississippi } \\
\text { River Industrial } \\
\text { Corridor }\end{array}$ & $1 \mathrm{~km}$ & $\begin{array}{l}\text { Racial minorities and } \\
\text { low-income population }\end{array}$ & $\begin{array}{l}\text { Computing the } \\
\text { comparative } \\
\text { environmental risk indices } \\
\text { (CERI) for minority and } \\
\text { populations in poverty } \\
\text { indices }\end{array}$ \\
\hline Ren et al., 2016 [33] & $\begin{array}{l}\text { Incinerator in } \\
\text { Shanghai, CHN }\end{array}$ & $3 \mathrm{~km}$ & $\begin{array}{c}\text { Three census groups } \\
\text { (socioeconomic status, } \\
\text { age, gender) }\end{array}$ & Willingness to accept \\
\hline $\begin{array}{l}\text { Pope et al., } \\
2016[34]\end{array}$ & $\begin{array}{c}\mathrm{O}_{3} \text { and } \mathrm{PM}_{10} \text { in } \\
\text { Phoenix, Arizona, US }\end{array}$ & No discussion & $\begin{array}{l}\text { Four census groups } \\
\text { (socioeconomic status, } \\
\text { age, race, and } \\
\text { ethnicity) }\end{array}$ & $\begin{array}{l}\text { Hierarchical multiple } \\
\text { regression models }\end{array}$ \\
\hline $\begin{array}{c}\text { Kramar et al., } \\
2017 \text { [35] }\end{array}$ & $\begin{array}{c}\text { Waste sites in } 48 \text { states } \\
\text { of the US }\end{array}$ & No discussion & $\begin{array}{c}\text { White and African } \\
\text { American }\end{array}$ & $\begin{array}{l}\text { Estimating an index of } \\
\text { gerrymandering }\end{array}$ \\
\hline $\begin{array}{l}\text { Rüttenauer and } \\
\text { Tobias, } 2017 \text { [36] }\end{array}$ & $\begin{array}{l}\text { Industrial facilities in } \\
\text { Germany }\end{array}$ & $2 \mathrm{~km}$ & $\begin{array}{c}\text { Minority } \\
\text { neighborhoods }\end{array}$ & $\begin{array}{l}\text { Allocating the } \\
\text { toxicity-weighted } \\
\text { emissions of facilities to } \\
\text { neighborhoods }\end{array}$ \\
\hline $\begin{array}{c}\text { Sarigiannis } \\
2017 \text { [37] }\end{array}$ & $\begin{array}{l}\text { Landfill sites and } \\
\text { incineration plants, } \\
\text { Athens, US }\end{array}$ & $12 \mathrm{~km}$ & Children & $\begin{array}{c}\text { Multi-route and } \\
\text { multi-pathway exposure } \\
\text { estimation }\end{array}$ \\
\hline Yuan, 2018 [38] & $\begin{array}{l}\text { Warehousing facilities } \\
\text { in LA, US }\end{array}$ & 0.5 mile & $\begin{array}{l}\text { White, Black, Latino } \\
\text { and Asian }\end{array}$ & $\begin{array}{c}\text { Simultaneous equation } \\
\text { model }\end{array}$ \\
\hline Yuan, 2019 [39] & $\begin{array}{l}\text { Warehouses and } \\
\text { distribution centers in } \\
\text { four metro areas in } \\
\text { California, US }\end{array}$ & No discussion & $\begin{array}{c}\text { Minority } \\
\text { neighborhoods }\end{array}$ & $\begin{array}{l}\text { Ordinary least squares and } \\
\text { spatial lag models }\end{array}$ \\
\hline
\end{tabular}

This study first introduces the data acquisition and research methods and then analyzes and discusses the results of the model. The last section concludes the paper, presents the main conclusions and offers some policy suggestions.

\section{Materials and Methods}

\subsection{Study Area}

The issue is investigated in 2019 based on 1700 apartments within a $10 \mathrm{~km}$ radius of 10 major MSWTFs in Shanghai (except Chongming District). Given that these apartments are rented to individuals, there are, theoretically, 1700 inhabitants in this study. A database is constructed to apply the HPM, including the real estate asking rent (sticker price), distance between the apartment and the MSWTF, housing information and neighborhood characteristics. The source of the data is the Shanghai Landscaping and City Appearance Administrative Bureau (SLCAA) [40] and the real estate agency databases. 
In recent years, Shanghai has built garbage collection and disposal stations throughout the entire city, thus creating a relatively perfect municipal solid waste disposal system. In late 2018, Shanghai (except for Chongming District) had 10 major MSWTFs (Figure 1) with a design disposal capacity of 23,700 tons per day, including 8 waste incineration plants, 1 waste landfill site and 1 waste composting plant. The actual waste treatment capacity of these MSWTFs is approximately 7.71 million tons per year.

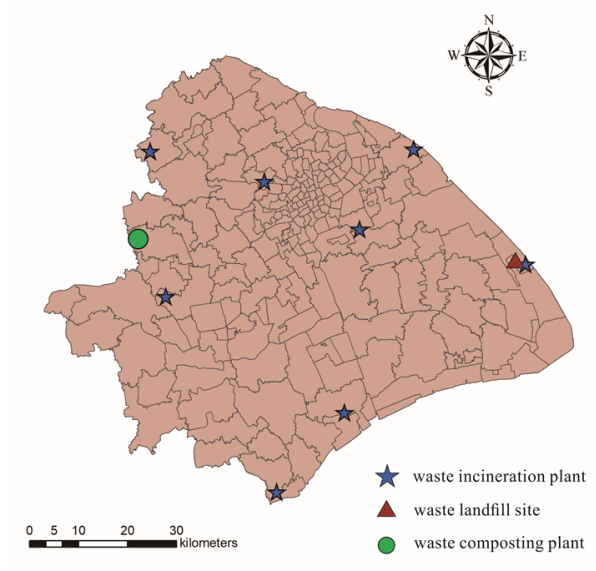

Figure 1. Map of waste treatment facilities.

\subsection{Variable Design}

Generally, residents consider factors such as housing type, living area and decoration when buying or renting apartments. For convenient travel and comfortable lifestyles, the location of nearby communal facilities is also regarded as a primary factor, which means that the price or rent of an apartment in close proximity of relevant facilities, such as bus stops and supermarkets, is higher than in areas without such conveniences. In addition, with the increased demand for improved quality of life, people pay more attention to the surrounding environment, including the issue for WTF site selection [41-44]. Some research found that environmental quality may be traded for increased quantities of other property characteristics, such as lower housing price, in the real estate market [45]. Therefore, this study hypothesizes that MSWTFs may have negative effects on housing rent. Based on previous studies [46,47], this study introduces independent variables into the HPM to correctly estimate the data affecting housing rent, including location (L), type of dwelling (D) and neighborhood (N). This study obtains detailed rental data with respect to housing rent and other independent variables, especially the distances between the house and nearby supermarkets, metro stations, hospitals, schools, parks and the central business district (CBD). Notably, the housing price is replaced with housing rent (R) in this study, given that more people are likely to rent their apartments than buy them because of the real estate situation and the consumption capacity of the poor. The data on housing rent in this paper were retrieved in 2019 from Beijing 58 Information Technology Co., Ltd., a real estate agency. Moreover, to ensure the thoroughness of the data, this study categorized the variable "decoration" into four classes according to the data source provided by the real estate agency. The data on public transport and other public facilities were obtained from the ArcGIS system. The name, symbol, definition and explanation of these selected variables are presented in Table 2. 
Table 2. Definition of selected variables.

\begin{tabular}{ccc}
\hline Type & Variables & Description \\
\hline Dependent variable & Rent & Housing rent (RMB/month) \\
\hline Location (L) & CBD & Distances between the property and the nearest CBD (m) \\
& MSWTF & Distances between the property and the nearest MSWTF (m) \\
\hline \multirow{2}{*}{ Dwelling (D) } & Area & Total apartment space $\left(\mathrm{m}^{2}\right)$ \\
& Decoration & Level of decoration (rank 1-4) \\
& Balcony & Apartment with balcony or not (no = 1, yes = 2) \\
\hline & Metro & Distance between the property and the nearest metro (m) \\
& Mart & Distance between the property and the nearest mart (m) \\
Neighborhood (N) & Park & Distance between the property and the nearest park (m) \\
& Hospital & Distance between the property and the nearest hospital (m) \\
& Bank & Distance between the property and the nearest bank (m) \\
\hline
\end{tabular}

\subsection{Stratification Scheme}

In previous studies, as demographic data are unavailable at the individual level, the dividing point between the rich and the poor was determined using the average percentage of the poverty line in the study area. This same percentage serves as the classification standard within the poverty scheme in the sample [48]. However, due to the randomness of the acquired data on housing rent, it is difficult to distinguish between the rich and the poor based on the ranking of housing rent. Given the definition of residents residing in more impoverished living conditions in the study of Shen et al. [49], the poor usually choose apartments without private bathrooms. Therefore, this study distinguishes between the rich and the poor according to those who live in apartments with or without private bathrooms, respectively, which means the difficulty of access to personal demographic data is avoided by applying this stratification scheme. Accordingly, there were 1100 and 600 data points in the poor group and the rich group, respectively. The HPM was then estimated for the data in the two groups to examine the environmental price discrimination between the poor and the rich in the next section.

\subsection{Model Building}

The HPM hypothesizes that housing price and housing rent are the combination of people's willingness to pay for various characteristic variables [50,51], which means that improving life quality and reducing costs for homes is implicit in the housing rent. For instance, in areas where MSWTFs cause environmental disamenity, housing prices may be lower than those of similar properties in areas without the effect of MSWTFs [27,52]. Put simply, to improve environmental attributes, individuals must bear higher housing prices. The HPM uses a regression model to internalize these characteristic variables into the housing prices to evaluate their impact [53]. Therefore, based on the HPM, the housing price or housing rent represents the combination of the characteristic variables $\left(C_{i}\right)$. Generally, the formats of the regression equation of the HPM, including linear, logarithmic and semilogarithmic models, are as denoted in Equations (1a)-(1c) [26]. In addition, the previous research subject of the HPM is housing prices. Given the purchasing power and preferences of the poverty-stricken population, this study substitutes rental data $(R)$ for housing prices.

Linear Model:

$$
R=\beta_{0}+\sum \beta_{i} C_{i}+\varepsilon
$$

Logarithmic Model:

$$
R=\beta_{0}+\beta_{i} \operatorname{Ln}\left(C_{i}\right)+\varepsilon
$$

Semilogarithmic Model:

$$
\operatorname{Ln}(R)=\beta_{0}+\beta_{i} C_{i}+\varepsilon
$$


where $R$ is the residential rental price; $\beta_{0}$ denotes the constants affected prices other than the characteristic variables; $\beta_{i}$ is the regression coefficient of the characteristic variables; $C_{i}$ represents the characteristic variables; and $\varepsilon$ represents the error correction coefficient.

To further examine the environmental price discrimination between the poor and the rich, the HPM was estimated for the two groups. The linear model is presented as an example (Equations (2a) and (2b)).

$$
\begin{gathered}
R_{A}=\alpha_{A} C B D_{A}+\beta_{A} M \operatorname{MSTF}_{A}+\gamma_{A} D_{A}+\delta_{A} N_{A}+\varepsilon_{A} \\
R_{B}=\alpha_{B} C B D_{B}+\beta_{B} M S W T F_{B}+\gamma_{B} D_{B}+\delta_{B} N_{B}+\varepsilon_{B}
\end{gathered}
$$

where subscripts $A$ and $B$ denote the groups of the poor and the rich, respectively; $R$ is the monthly payment for housing rent; $C B D$ represents the distances between the property and the nearest $C B D ; \alpha$ is the regression coefficient of the $C B D$ to $R$; and MSWTF, which is the indicator of environmental quality used in this study, is the other characteristic variable of location (L) parameterized by $\beta$. Similarly, $D$ and $N$ represent the characteristic variables of dwelling and neighborhood, respectively; $\delta$ and $\gamma$ are the regression coefficients of dwelling and neighborhood, respectively; and $\varepsilon$ is the error correction coefficient. The contents of dwelling and neighborhood are presented in Table 2.

After establishing the model, the regression result was used to estimate monthly housing rent. The coefficient of MSWTF, which implies an implicit price of environmental quality, was then obtained. Once the model was estimated, a method of counterfactual decomposition was used to predict the housing prices of one group of people given the environmental quality characteristics of the other group. These predictions were then compared to their own predicted housing prices. The new housing rent was predicted using the counterfactual decomposition method and exchanging the coefficients of groups A and B. Finally, the new housing rent was compared with the actual housing rent of the two groups. The formats of the counterfactual decomposition are as denoted in Equations (3a)-(4b).

$$
\begin{gathered}
R_{A}=\alpha_{A} C B D_{A}+\beta_{B} M S W T F_{A}+\gamma_{A} D_{A}+\delta_{A} N_{A}+\varepsilon_{A} \\
R_{B}=\alpha_{B} C B D_{B}+\beta_{A} M S W T F_{B}+\gamma_{B} D_{B}+\delta_{B} N_{B}+\varepsilon_{B} \\
\triangle R_{A}=R_{A \mid B}-R_{B \mid A} \\
\triangle R_{B}=R_{B \mid A}-R_{A \mid B}
\end{gathered}
$$

Note that person $i$ in group A cannot normally reach the same level as a person from group $\mathrm{B}$, and thus, the environmental cost in group $A$ is displaced by this type of imbalance in group B in Equation (3a). Moreover, maintaining the constancy of the other characteristic coefficients eliminates other forms of discrimination and maintains the initial choice of attribute combination. Using the data of group A as an example, $R_{A}$ represents the regression result of the housing rent of the poor when people pay for their own environmental pressure, while $R_{A \mid B}$ is the regression value under the condition in which the poor enjoy the environmental quality experienced by the rich. The $\Delta R_{A}$ denotes the difference between the two predicted housing rents $R_{A}$ and $R_{A \mid B}$. This study determines whether the poor are subjected to a lower level of environmental quality by examining the $\Delta R_{A}$. If the situation of the poor is indeed worse than that of the rich, then the value of the $\triangle R_{A}$ will increase significantly. A similar operation is performed to generate $R_{B}, R_{B \mid A}$ and $\triangle R_{B}$.

\section{Results}

\subsection{Model Verification}

This study evaluates the goodness of fit of the model using $R^{2}$, which is the total percentage of squares explained by the regression equation. There is a better fitting of the regression model when $\mathrm{R}^{2}$ trends to $100 \%$. In this study, because the amount of data is large (approximately 1700 data points), this study does not find that the value of $R^{2}$ is significantly different from that of the adjusted $R^{2}$. Thus, 
$\mathrm{R}^{2}$ is used to evaluate the fitting. IBM SPSS [54], an instrument frequently used to conduct various social sciences data analyses, was used to examine the fitting of the three models for groups A and B. The hedonic regression results are reported in Table 3.

Table 3. Results of Multiple Regression Models.

\begin{tabular}{cccccc}
\hline Group & Model & $\mathbf{R}$ & $\mathbf{R}^{\mathbf{2}}$ & $\mathbf{P}$ & $\boldsymbol{\varepsilon}$ \\
\hline \multirow{3}{*}{ A } & Linear model & 0.897 & 0.804 & 0.000 & 560.132 \\
& Logarithmic model & 0.916 & 0.839 & 0.000 & 126.942 \\
& Semilogarithmic model & 0.894 & 0.800 & 0.000 & 398.472 \\
\hline \multirow{2}{*}{ B } & Linear model & 0.913 & 0.833 & 0.000 & 235.898 \\
& Logarithmic model & 0.729 & 0.532 & 0.000 & 299.790 \\
& Semilogarithmic model & 0.884 & 0.781 & 0.000 & 229.296 \\
\hline
\end{tabular}

When comparing the above parameters, it is noted that the $\varepsilon$ values of the models are relatively similar, albeit the regression parameter of the linear model is significantly smaller. In addition, the linear model attains relatively high $R^{2}$ and $F$ values, thus suggesting that the regression equation exhibits high significance. Thus, a linear model is established for the regression analysis of the relevant data, which results in the following regression equation: $R=\beta_{0}+\sum \beta_{i} C_{i}+\varepsilon$ (1a).

This study tests the residual error of the data from the poor and the rich as displayed in the histogram of the regression standardized residual (Figure 2 above) and the normal p-p plot of the regression standardized residual (Figure 2 below). With respect to the residual error of the linear model, the histogram of the regression standardized residual matches symmetrically the curve of normal distribution, indicating that the residual error distribution is approximate to the normal distribution. Simultaneously, because all points were around the regression line, as presented in the normal p-p plot of the regression standardized residual, it is concluded that the data are normally distributed.
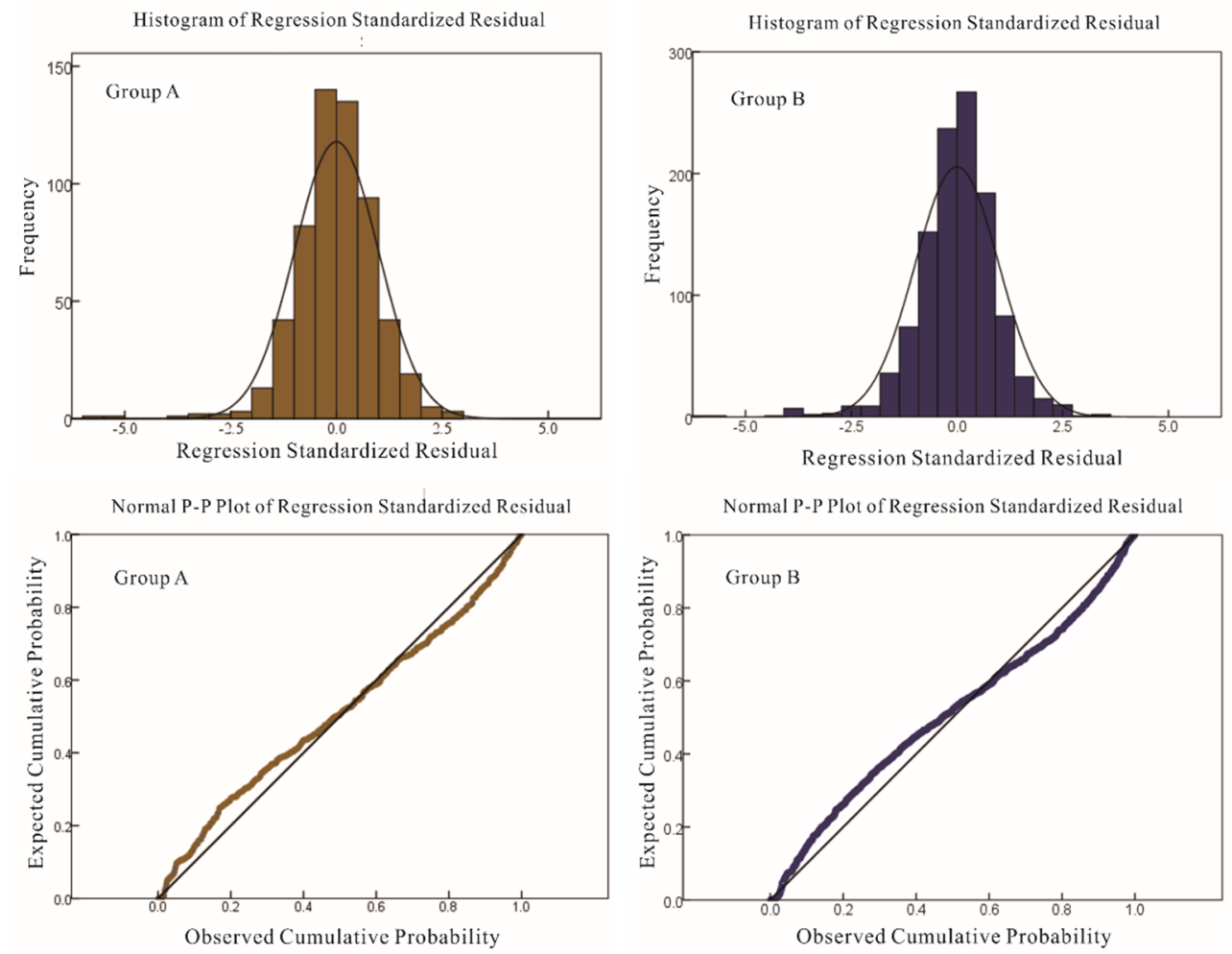

Figure 2. Histogram and normal p-p plot of the regression standardized residual in the linear model. 


\subsection{Descriptive Statistics}

Table 4 presents the regression results of the poor (group A) and the rich (group B). With respect to group A, the poor, the coefficient of the continuous variables with actual values for MSWTF $(0.131)$ indicates that the housing rent increases by RMB 131 per $1 \mathrm{~km}$ increase in the distance between an apartment and the MSWTF, on average, when the other characteristic variables remain unchanged. Regarding group B, the rich, the coefficient of the continuous variables with actual values of MSWTF (0.057) indicates that the housing rent increases by RMB 57 per $1 \mathrm{~km}$ increase in the distance between an apartment and the MSWTF, on average, when the other characteristic variables remain unchanged. These results reveal that the shorter the distance is between the residential area and the MSWTF, the lower the housing rent is. Similarly, for the poor, the coefficient of CBD is -0.121 , indicating that when the other characteristic variables remain unchanged, the housing rent decreases by RMB 121 for every $1 \mathrm{~km}$ increase in the distance from the CBD, whereas for the rich, the coefficient of CBD is -0.186 , indicating that when the other characteristic variables remain unchanged, the housing rent decreases by RMB 186 for every $1 \mathrm{~km}$ increase in the distance from the CBD. These findings suggest that the closer the apartment is to the $\mathrm{CBD}$, the higher the housing rent is. For variables discriminated by level, such as the variable of decoration, which is evaluated based on four classes, the coefficients are 372.969 and 449.210 for the poor and the rich, respectively, thus indicating that whenever the decoration increases one level, the housing rent increases by approximately RMB 373 and 449, respectively, for these two groups. Similar explanations can be presented for the other variables. Note that symbols should be simultaneously considered.

Table 4. Regression coefficient of variables in the linear model.

\begin{tabular}{|c|c|c|c|c|c|c|}
\hline \multirow{2}{*}{ Group } & \multirow{2}{*}{ Variables } & \multicolumn{2}{|c|}{ Coefficient } & \multirow{2}{*}{$\begin{array}{c}\text { Standardized Coefficients } \\
\text { Beta }\end{array}$} & \multirow{2}{*}{$t$} & \multirow{2}{*}{ Sig. } \\
\hline & & B & Standard Error & & & \\
\hline \multirow{11}{*}{ A } & Constant & -130.819 & 363.766 & & -0.36 & 0.719 \\
\hline & CBD & -0.121 & 0.013 & -0.269 & -9.359 & 0 \\
\hline & MSWTF & 0.131 & 0.021 & 0.134 & 6.38 & 0 \\
\hline & Area & 47.617 & 1.317 & 0.751 & 36.168 & 0 \\
\hline & Decoration & 372.969 & 95.778 & 0.086 & 3.894 & 0 \\
\hline & Balcony & 527.798 & 117.36 & 0.089 & 4.497 & 0 \\
\hline & Bank & -0.031 & 0.055 & -0.014 & -0.554 & 0.58 \\
\hline & Hospital & -0.185 & 0.063 & -0.067 & -2.923 & 0.004 \\
\hline & Mart & 0.023 & 0.058 & 0.009 & 0.395 & 0.693 \\
\hline & Metro & 0.067 & 0.089 & 0.018 & 0.754 & 0.451 \\
\hline & Park & 0.033 & 0.089 & 0.01 & 0.372 & 0.71 \\
\hline \multirow{11}{*}{ B } & Constant & -7042.547 & 1963.288 & & -3.587 & 0 \\
\hline & CBD & -0.186 & 0.038 & -0.105 & -4.884 & 0 \\
\hline & MSWTF & 0.057 & 0.072 & 0.01 & 0.794 & 0.427 \\
\hline & Area & 131.800 & 2.017 & 0.903 & 65.35 & 0 \\
\hline & Decoration & 449.210 & 528.405 & 0.011 & 0.85 & 0.395 \\
\hline & Balcony & 2469.432 & 567.642 & 0.055 & 4.35 & 0 \\
\hline & Bank & 0.369 & 0.206 & 0.031 & 1.791 & 0.073 \\
\hline & Hospital & -0.557 & 0.22 & -0.043 & -2.533 & 0.011 \\
\hline & Mart & 0.212 & 0.179 & 0.021 & 1.183 & 0.237 \\
\hline & Metro & 0.334 & 0.156 & 0.034 & 2.136 & 0.033 \\
\hline & Park & 0.002 & 0.298 & 0 & 0.005 & 0.996 \\
\hline
\end{tabular}

There are significant differences in the influencing degree of the characteristic variables on housing rent. The most influential variables are the area of the apartment (beta $=0.751$ ) and the distance between the apartment and the CBD (beta $=-0.269$ ), the latter of which has the greatest impact on residential buildings owing to the strong regional characteristics in Shanghai. Moreover, this study finds that the distance from the apartment to solid waste disposal facilities is an important influencing factor and that the distance variable of solid waste facilities $(B=0.134)$ is an important variable, thus indicating that the main MSWTF in Shanghai has a strong negative external impact on the unit rent of surrounding ordinary residential apartments. 


\subsection{Quantitative Assessments}

This study quantitatively assessed the disproportionate impact of the variables by comparing the value of the unstandardized coefficient (B) among different groups. The unstandardized coefficient is often regarded as the influencing degree of the corresponding dependent variable on the independent variable when the other variable remains unchanged. Moreover, it could also be considered the cost of enjoying certain benefits or the cost associated with avoiding environmental hazards. The poor pay RMB 131 per km they move away from the MSWTF. However, to avoid living near an MSWTF, ordinary citizens pay only RMB 57 per $\mathrm{km}$. Compared with ordinary citizens, the poor encounter greater difficulty when attempting to eliminate the effects of MSWTFs. In addition, this study compared the beta of the disposition of the two groups and concluded that the greater value of group A's beta $(0.134)$ indicates that MSWTFs have a more significant impact on housing rent than do the other variables when compared with group B's beta (beta $=0.01$ ).

Predicting housing rent according to the framework presented in Equations (3a) and (4a) indicates that the poor can obtain enormous benefits if they pay the same implicit environmental cost as that paid by the rich. Specifically, the predicted monthly housing rent of the poor would be RMB 3392 if they could afford the environmental quality cost of the rich, which is approximately RMB 420 less per month than the RMB 3812 of their own stratum. Conversely, if rich households pay the environmental quality cost of the poor, then their predicted monthly payment for housing rent would be approximately $110 \%$ of the actual payment, which represents an increase from RMB 5215 to RMB 5754.

\section{Discussion and Conclusions}

This article explores EJ by incorporating counterfactual decomposition into the HPM. First, an HPM was established to test the environmental price discrimination between the poor and the rich in housing rent markets where environmental disamenities exist. Next, unlike previous HPM studies, a test based on counterfactual decomposition analysis was proposed by exchanging the unstandardized coefficient of MSWTF in this research. If the poor and the rich face the same implicit environmental price, then the difference in housing rent between the two groups of people would diminish or be eliminated. These results support those of previous studies regarding environmental price discrimination related to poor households. Thus, this method calculates the extent of the losses in environmental quality, which can offer guidance on EJ research to researchers. In addition to measuring the influence degree of environmental disamenities, our findings attempt to offer practical guidance to agency officials, planners, or policy advocates seeking to produce objective, valid measures of EJ. There are a several additional important findings.

First, the disamenity of MSWTFs is hypothesized to negatively influence adjacent housing rent. The importance of MSWTFs confirmed by the regression result is consistent with previous studies that conclude that environmental elements highly influence housing prices. Even the importance of environmental requirements goes far beyond traditional neighborhood factors, which suggests that people may especially focus on the impact of MSWTFs and that the impact is regarded as important for both the poor and the rich.

Second, the tests based on the difference in the unstandardized coefficient of the HPM declare the presence of underlying environmental price discrimination against the poor with respect to environmental quality. On the one hand, if the poor and the rich face the same implicit environmental price, then the difference in housing rent between the two groups of people would diminish or be eliminated. On the other hand, if people face the same pressure from housing rent, then the rich would significantly increase their probability of living near an MSWTF, while the poor would live better than they do. The test results of EJ appear to reinforce each other through the dependent variable of housing rent and the distance to an MSWTF. Based on these analyses, it is inferred that the poor actually pay a higher implicit price for environmental quality than do the rich.

Third, unlike previous conclusions that vulnerable groups are more likely located near high levels of toxins in disproportionate numbers than are others, the result of the HPM may not be sensitive 
to the observed spatial agglomeration and rather may focus on the marginal cost for environmental improvement changes due to distance. Given the extent of the residential aggregation of race and ethnicity in Chinese cities, such as Shanghai, it is difficult to observe the residential segregation around MSWTFs. However, this difficulty does not affect the appearance of environmental injustice between the poor and the rich, as proven by the coefficient of MSWTF in the HPM. Moreover, the conventional techniques of spatial interpolation and analytical buffering in other studies appear to substantiate the results at the city level.

Although the results of tests based on different techniques appear to reinforce one another, some questions regarding the application of the HPM are still worthy of further study and discussion. First, as the analysis is based on market transaction data from housing agents, the data cannot reflect the values of houses or apartments that are not traded during the sampling period. In addition, the data on apartments do not include the data on those units sold by owners. Second, MSWTFs may be located near other hazardous sites, which also generate disamenity. Hence it is difficult to isolate the effect of MSWTFs on the surrounding houses or apartments, and as a consequence, this study overemphasizes the damage caused by MSWTFs. Third, although the number of observations is large, the data on individual household characteristics are not sufficiently detailed. Therefore, future research on EJ can be improved through increased data collection at both the individual and household levels.

Author Contributions: Conceptualization, Y.C.; Data curation, J.T.; Investigation, L.C.; Writing—original draft, C.Z. All authors have read and agreed to the published version of the manuscript.

Funding: This research was funded by [the Science and Technology Commission of Shanghai Municipality], grant number [19DZ1204604].

Conflicts of Interest: The authors declare no conflict of interest.

\section{References}

1. Bullard, R.D.; Johnson, G.S. Environmental justice: Grassroots activism and its impact on public policy decision making. J. Soc. Sci. 2000, 56, 555-578.

2. Gross, B.H.; Shafsky, H.; Brown, K. Environmental justice: A review of state responses. West-Northwest J. Environ. Law Policy 2001, 8, 41-269.

3. Banzhaf, S.; Ma, L.; Timmins, C. Environmental justice: The economics of race, place, and pollution. J. Econ. Perspect. 2019, 33, 185-208. [CrossRef] [PubMed]

4. Ash, M.; Boyce, J.K.; Chang, G.; Scharber, H.; Lineberry, R.L. Is environmental justice good for white folks? industrial air toxics exposure in urban America. Soc. Sci. Q. 2013, 94, 616-636. [CrossRef]

5. Pais, J.; Crowder, K.; Downey, L. Unequal trajectories: Racial and class differences in residential exposure to industrial hazard. Soc. Forces 2014, 92, 1189-1215. [CrossRef]

6. Pellow, D.; Vazin, J. The Intersection of Race, Immigration Status, and Environmental Justice. Sustainability 2019, 11, 3942. [CrossRef]

7. Harner, J.; Warner, K.; Pierce, J.; Huber, T. Urban environmental justice indices. Prof. Geogr. 2010, 54, 318-331. [CrossRef]

8. Satterfield, T.A.; Mertz, C.K.; Slovic, P.; Analysis, R. Discrimination, vulnerability, and justice in the face of risk. Risk Anal. 2010, 24, 115-129. [CrossRef]

9. Sheppard, E.; Leitner, H.; McMaster, R.B.; Tian, H. GIS based measures of environmental equity: Exploring their sensitivity and significance. J. Expo. Anal. Environ. Epidemiol. 1999, 9, 18-28. [CrossRef]

10. United States Environmental Protection Agency (EPA). Available online: https://search.epa.gov/epasearch/ ?querytext=Environmental+Justice\&areaname $=\&$ areacontacts=\&areasearchurl=\&typeofsearch $=$ epa\& result_template $=2$ col.ftl\#/ (accessed on 27 March 2020).

11. Johnson, T.; Lora-Wainwright, A.; Lu, J. The quest for environmental justice in China: Citizen participation and the rural-urban network against Panguanying's waste incinerator. Sustain. Sci. 2018, 13, 733-746. [CrossRef]

12. Lora-Wainwright, A.; Zhang, Y.; Wu, Y.; Van Rooij, B. Learning to live with pollution: The making of environmental subjects in a Chinese industrialized village. China J. 2012, 68, 106-124. [CrossRef] 
13. Steinhardt, H.; Wu, F. In the name of the public: Environmental protest and the changing landscape of popular contention in China. China J. 2016, 75, 61-82. [CrossRef]

14. Mcmaster, R.B.; Leitner, H.; Sheppard, E. GIS-based environmental equity and risk assessment: Methodological problems and prospects. Cartogr. Geogr. Inf. Sci. 1997, 24, 172-189. [CrossRef]

15. Walker, G.; Mitchell, G.; Fairburn, J.; Smith, G. Industrial pollution and social deprivation: Evidence and complexity in evaluating and responding to environmental inequality. Local Environ. 2005, 10, 361-377. [CrossRef]

16. Mohai, P.; Saha, R. Racial inequality in the distribution of hazardous waste: A national-level reassessment. Soc. Probl. 2007, 54, 343-370. [CrossRef]

17. Maantay, J. Mapping environmental injustices: Pitfalls and potential of geographic information systems in assessing environmental health and equity. Environ. Health Perspect. 2002, 110, 161-171. [CrossRef] [PubMed]

18. Saha, R.; Mohai, P. Historical context and hazardous waste facility siting: Understanding temporal patterns in Michigan. Soc. Probl. 2005, 52, 618-648. [CrossRef]

19. Higgs, G.; Langford, M. Giscience, environmental justice, \& estimating populations at risk: The case of landfills in wales. Appl. Geogr. 2009, 29, 63-76.

20. Noonan, D.S.; Turaga, R.M.R.; Baden, B.M. Superfund, hedonics, and the scales of environmental justice. Environ. Manag. 2009, 44, 909-920. [CrossRef]

21. Won, J.; Lee, J. Investigating how the rents of small urban houses are determined: Using spatial hedonic modeling for Urban Residential Housing in Seoul. Sustainability 2017, 10, 31. [CrossRef]

22. Brasington, D.M.; Hite, D. Demand for environmental quality: A spatial hedonic analysis. Reg. Sci. Urban Econ. 2003, 35, 57-82. [CrossRef]

23. Deaton, B.J.; Hoehn, J.P. Hedonic analysis of hazardous waste sites in the presence of other urban disamenities. Environ. Sci. Policy 2004, 7, 499-508. [CrossRef]

24. Hughes, M.A.; Madden, J.F. Residential segregation and the economic status of black workers: New evidence for an old debate. J. Urban Econ. 1991, 29, 28-49. [CrossRef]

25. Oaxaca, R. Male-female wage differentials in urban labor markets. Int. Econ. Rev. 1973, 14, 693-709. [CrossRef]

26. Eshet, T.; Baron, M.G.; Shechter, M.; Ayalon, O. Measuring externalities of waste transfer stations in Israel using hedonic pricing. Waste Manag. 2007, 27, 614-625. [CrossRef] [PubMed]

27. Hite, D.; Chern, W.; Hitzhusen, F.; Randall, A. Property-value impacts of an environmental disamenity: The case of landfills. J. Real Estate Financ. Econ. 2001, 22, 185-202. [CrossRef]

28. Ihlanfeldt, K.R.; Taylor, L.O. Externality effects of small-scale hazardous waste sites: Evidence from urban commercial property markets. J. Environ. Econ. Manag. 2004, 47, 117-139. [CrossRef]

29. Kiel, K.A.; Williams, M. The impact of Superfund sites on local property values: Are all sites the same? J. Urban Econ. 2007, 61, 170-192. [CrossRef]

30. Yeboah, O.; Thomas, T.; Foster, T.; Fosu, E. Pollution, environmental justice, and the North Carolina pork industry. In Proceedings of the 2007 National Conference on Environmental Science and Technology, 1st ed.; Nzewi, E., Reddy, G., Luster-Teasley, S., Kabadi, V., Chang, S.Y., Schimmel, K., Uzochukwu, G., Eds.; Springer: New York, NY, USA, 2009; Volume 1, pp. 127-137.

31. Giordano, A.; Cheever, L. Using dasymetric mapping to identify communities at risk from hazardous waste generation in San Antonio, Texas, USA. Urban Geogr. 2010, 31, 623-647. [CrossRef]

32. Perera, P.K.R.; Lam, N. An environmental justice assessment of the mississippi river industrial corridor in Louisiana, U.S. using a GIS-based approach. Appl. Ecol. Environ. Res. 2013, 11, 681-697. [CrossRef]

33. Ren, X.Y.; Che, Y.; Yang, K.; Tao, Y. Risk perception and public acceptance toward a highly protested waste-to-energy facility. Waste Manag. 2016, 48, 528-539. [CrossRef] [PubMed]

34. Pope, R.; Wu, J.; Boone, C. Spatial patterns of air pollutants and social groups: A distributive environmental justice study in the phoenix metropolitan region of USA. Environ. Manag. 2016, 58, 753-766. [CrossRef] [PubMed]

35. Kramar, D.E.; Anderson, A.; Hilfer, H.; Branden, K.; Gutrich, J.J. A spatially informed analysis of environmental justice: Analyzing the effects of gerrymandering and the proximity of minority populations to U.S. superfund sites. Environ. Justice 2017, 11, 29-39. [CrossRef] 
36. Rüttenauer, T. Neighbours matter: A nation-wide small-area assessment of environmental inequality in Germany. Soc. Sci. Res. 2017, 70, 198-211. [CrossRef] [PubMed]

37. Sarigiannis, D. Assessing the impact of hazardous waste on children's health: The exposome paradigm. Environ. Res. 2017, 158, 531-541. [CrossRef] [PubMed]

38. Yuan, Q. Mega freight generators in my backyard: A longitudinal study of environmental justice in warehousing location. Land Use Policy 2018, 76, 130-143. [CrossRef]

39. Yuan, $Q$. Does context matter in environmental justice patterns? evidence on warehousing location from four metro areas in California. Land Use Policy 2019, 82, 328-338. [CrossRef]

40. Shanghai Landscaping and City Appearance Administrative Bureau (SLCAA). Available online: https://data.sh.gov.cn/view/detail/index.html?type=cp\&\&id=AH2002015024\&\&dataset_name=\%E7\%84\% 9A\%E7\%83\%A7\%E5\%8E\%82\%E4\%BF\%A1\%E6\%81\%AF (accessed on 27 March 2020).

41. Jim, C.Y.; Chen, W.Y. Consumption preferences and environmental externalities: A hedonic analysis of the housing market in Guangzhou. Geoforum 2007, 38, 414-431. [CrossRef]

42. Zhao, L.; Zou, J.; Zhang, Z. Does China's Municipal Solid Waste Source Separation Program Work? Evidence from the Spatial-Two-Stage-Least Squares Models. Sustainability 2020, 12, 1664. [CrossRef]

43. Hu, H.; Li, X.; Nguyen, A.D.; Kavan, P. A Critical Evaluation of Waste Incineration Plants in Wuhan (China) Based on Site Selection, Environmental Influence, Public Health and Public Participation. Int. J. Environ. Res. Public Health 2015, 12, 7593-7614. [CrossRef]

44. Wang, J.; Ye, X.; Wei, Y.D. Effects of Agglomeration, Environmental Regulations, and Technology on Pollutant Emissions in China: Integrating Spatial, Social, and Economic Network Analyses. Sustainability 2019, 11, 363. [CrossRef]

45. Chaliki, P.; Psomopoulos, C.S.; Themelis, N.J. WTE plants installed in european cities: A review of success stories. Manag. Environ. Qual. Int. J. 2016, 27, 606-620. [CrossRef]

46. Boyle, M.; Kiel, K.A. A survey of house price hedonic studies of the impact of environmental externalities. J. Real Estate Lit. 2001, 9, 117-144.

47. Rivas Casado, M.; Serafini, J.; Glen, J.; Angus, A. Monetising the impacts of waste incinerators sited on brownfield land using the hedonic pricing method. Waste Manag. 2017, 61, 608-616. [CrossRef]

48. Hite, D. A random utility model of environmental equity. Growth Chang. 2000, 31, 40-58. [CrossRef]

49. Shen, Y.; Sun, F.; Che, Y. Public green spaces and human wellbeing: Mapping the spatial inequity and mismatching status of public green space in the central city of shanghai. Urban For. Urban Green. 2017, 27, 59-68. [CrossRef]

50. Lancaster, K.J. A new approach to consumer theory. J. Political Econ. 1966, 74, 132-157. [CrossRef]

51. Muth, R.F. Household production and consumer demand functions. Econometrica 1966, 34, $699-708$. [CrossRef]

52. Segerson, K. Real estate and the environment: An introduction. J. Real Estate Financ. Econ. 2001, 22, 135-139. [CrossRef]

53. Rosen, S. Hedonic prices and implicit markets: Product differentiation in pure competition. J. Political Econ. 1974, 82, 34-55. [CrossRef]

54. IBM SPSS Statistics. Available online: https://www.ibm.com/cn-zh/products/spss-statistics/pricing?lnk= STW_CN_HP_T1_TL\&psrc=NONE\&pexp=DEF\&lnk2=goto_SPSSstat (accessed on 10 April 2020).

(C) 2020 by the authors. Licensee MDPI, Basel, Switzerland. This article is an open access article distributed under the terms and conditions of the Creative Commons Attribution (CC BY) license (http://creativecommons.org/licenses/by/4.0/). 